\title{
Quality characteristics of semi-dried persimmons soaked in different concentration of sugar solution
}

\author{
Gi-Man Kwon ${ }^{1}$, Jae-Won Kim² ${ }^{2}$, Kwang-Sup Youn ${ }^{1,3}$ * \\ ${ }^{1}$ Department. of Food Science and Technology, Catholic University of Daegu, Gyeongsan 712-702, Korea \\ ${ }^{2}$ Orye Life Science Co., Ltd., Busan 601-060, Korea \\ ${ }^{3}$ Institute of Food Science and Technology, Catholic University of Daegu, Gyeongsan 712-702, Korea
}

\section{당액침지에 따른 반건시 가공품의 품질특성}

\author{
권기만 ${ }^{1} \cdot$ 김재원 $^{2} \cdot$ 윤광섭 $^{1,3 *}$ \\ ${ }^{1}$ 대구가톨릭대학교 식품공학과, ${ }^{2}$ 오례생명과학(주), ${ }^{3}$ 대구가톨릭대학교 식품과학연구소
}

\begin{abstract}
This study was conducted to investigate the quality and characteristics of semi-dried persimmons soaked in different concentrations of sugar solution and stored at $7^{\circ} \mathrm{C}$ for 20 days. The $L$ value and chroma value were significantly higher in S5 and S10 compared to the other concentrations of sugar solution. The $\mathbf{E}$ and browning degree were increased according to the increase in concentration of sugar solution. Total sugar, reducing sugar, and sugar free contents were higher in the control (semi-dried persimmon) than those in S0, but they increased according to the increase in concentration of sugar solution. Polyphenol oxidase and peroxidase activities were decreased according to the increase in sugar solution concentration, which were highest in S0 among other semi-dried persimmons soaked in sugar solutions. Total ascorbic acid content was highest in S10 (12.29 mg/g), followed by S0 $(2.54 \mathrm{mg} / \mathrm{g})$, S5 $(7.76 \mathrm{mg} / \mathrm{g}), S 15(6.05 \mathrm{mg} / \mathrm{g})$, and $\mathrm{S20}(5.05 \mathrm{mg} / \mathrm{g})$. Total polyphenols, flavonoids and proanthocyanidins contents were the highest in S10 compared to other semi-dried persimmons soaked in sugar solutions. Furthermore, the same tendency was observed with DPPH radical scavenging ability. These results showed that $10 \%$ sugar solution could be applied to semi-dried persimmons in order to achieve high quality, nutritional value, and browning inhibition.
\end{abstract}

Key words : Diospyros kaki, semi-dried persimmon, sugar solution, soaking

\section{서 론}

감(Diospyros $\mathrm{kaki})$ 은 우리나라의 3대 과실 중의 하나로 남부지역을 중심으로 넓은 지역에서 생산되며(1) 포도당, 과당 등의 당질과 비타민 $\mathrm{A}$ 와 $\mathrm{C}$ 같은 영양소뿐만 아니라 $\mathrm{Ca}, \mathrm{K}, \mathrm{Mg}$ 등의 무기염류가 풍부한 알칼리성 식품이다(2). 감은 기침 등에 효과가 있으며, 다른 과실과 달리 신맛이 없고 탄닌의 수렴작용으로 설사를 멎게 하거나 이뇨, 지혈,

*Corresponding author. E-mail : ksyoun@cu.ac.kr

Phone : 82-53-850-3209, Fax : 82-53-850-3209

Received 13 February 2015; Revised 8 April 2015; Accepted 13 April 2015.

Copyright (C) The Korean Society of Food Preservation. All rights reserved.
숙취제거, 기침 등의 약리작용을 나타내어 예로부터 많이 사용되어온 기능성이 우수한 전통 과일 중의 하나이다(3).

최근에는 기술력 향상으로 다양한 형태의 감 말랭이, 감 퓌레, 감 식초, 감 와인 등의 가공식품이 생산되고 있다. 이중 반건시는 홍시와 곶감의 중간 정도의 식감을 가진 식품의 형태로, 풍부한 단맛과 특유의 물리적 특성이 더해 져 촉촉한 식감을 가지고 있어 선호도가 매우 높은 편이며 앞으로도 수요가 커질 것으로 기대되는 고부가가치 상품이 다(4). 하지만 기존의 건조식품과는 달리 연한 조직과 수분 이 많은 특징 때문에 미흡한 보관 상태에서 장기간 유통하 게 되면 곰팡이, 유충 등의 발생으로 위생상태가 급속히 떨어지게 된다(5). 또한, 장기간 보관할 경우 저온장해가 발생하여 저장성이 낮아지며 운송과 유통에서 냉동 및 냉장 시스템(cold system)을 필요하므로 단가가 높이 형성되어 
있다. 저장성을 연장하는 가공방법의 부재로 유통기한 이 후의 제품은 모두 폐기되고 있는 실정에 따라 이를 개선할 수 있는 가공 및 기술 개발이 시급한 실정이다.

당액침지는 삼투효과로 고상식품을 높은 삼투압의 당 용액에 침지하여 농축하는 유용한 방법으로서 식품과 용액 간의 용질 확산 및 용액 속으로의 수분 이동(6)과 식품으로 부터 당, 유기산, 미네랄 등 성분들의 용출 현상(7)으로 식품 의 기호성을 향상하고 저장성을 높이기 위하여 사용되는 방법이다. 당액침지에 사용되는 재료의 특성에 따라 다양 한 침지액을 조성할 수 있고, 침지액 또한 침지물질에 들어 있는 영양소가 녹아 있어 그대로 마실 수 있다는 장점이 있다 $(8,9)$. 이러한 가공방법은 식품의 비타민, 향기, 색소 성분의 손실을 막아줄 뿐만 아니라 기존의 풍미를 더욱더 증가시키고 저장성까지 높여줄 수 있어 단순하지만 가장 상용화되기 쉽고 파급효과가 크다는 장점이 있어 반건시에 도 접목할 가능성이 큰 것으로 생각된다.

따라서 본 연구에서는 반건시의 가공적 활용방안을 위한 목적으로 당액침지 타입의 반건시 제품을 제조하고자 하였 으며, 당액침지에 따른 품질변화를 비교 분석하고 품질유 지에 적합한 반건시의 제품화를 위한 기초자료를 제시하고 자 하였다.

\section{재료 및 방법}

재 료

본 실험에 사용된 반건시는 청도대감영농조합법인에서 공급받아 사용하였으며, 당액 제조에 사용된 감미료는 설 탕(CJ-Beksul, Inchun, Korea), xylitol(Roquette Freres, France), polydextrose(Samyang, Inchun, Korea), crystalline
fructose(TATE\&LYLE Ingredients Americas, Inc, USA), xanthan gum(Samwoo T/D, Seoul, Korea), guar gum(Shree Vijay Laxmi Enterrrises, India), 비타민 C(Shinwon Cheivlcal All Fighs Seserved, Seoul, China), citric acid (JUNGBUNZLAUER Austria AG, Austria), chicory fiber (Cosucra, Belgium) 및 stevia(Daepyung, Sangju, Korea)를 실험에 사용하였다.

\section{시료의 추출}

당액침지 반건시의 항산화 성분 함량 및 활성을 분석하 기 위하여 침지액은 여과하여 시료로 사용하였고, 반건시 는 건조한 분말을 $70 \%$ 에탄올 용매에 $1: 10$ 의 비율로 넣고 24시간 추출한 후 Whatman No. 2 여과지로 여과하여 얻은 여액을 분석용 시료로 사용하였다.

\section{당액침지 반건시 제조}

당액침지 반건시의 제조공정은 Fig. 1과 같다. 반건시를 침지하지 않은 것은 대조구(control)로 나타냈으며, 당액의 조성은 Table 1과 같이 배합비율을 정하여 물 $100 \mathrm{~g}$ 을 기준 으로 설탕을 $0,5,10,15,20 \%$ 로 각각 첨가하여 제조 후 $7^{\circ} \mathrm{C}$ 에서 20 일간 저장하였다. 당액의 제조는 반건시와 조화 도가 높은 레시피 확립과 맛, 영양 및 약리작용과 풍미를 가미하고자 계피 및 생강분말을 열수에 추출한 다음 여과한 여과액에 xylitol, crystalline fructose, polydextrose, xanthan fum, guar gum, chicory fiber, stevia, citric acid, 비타민 C를 첨가하여 혼합 및 교반하였다. 각각의 조건으로 제조된 당 액 조성액 $100 \mathrm{~mL}$ 에 크기가 일정한 반건시 $(90 \pm 3 \mathrm{~g})$ 를 침지 하여 기호특성 및 품질을 비교 분석하였다.

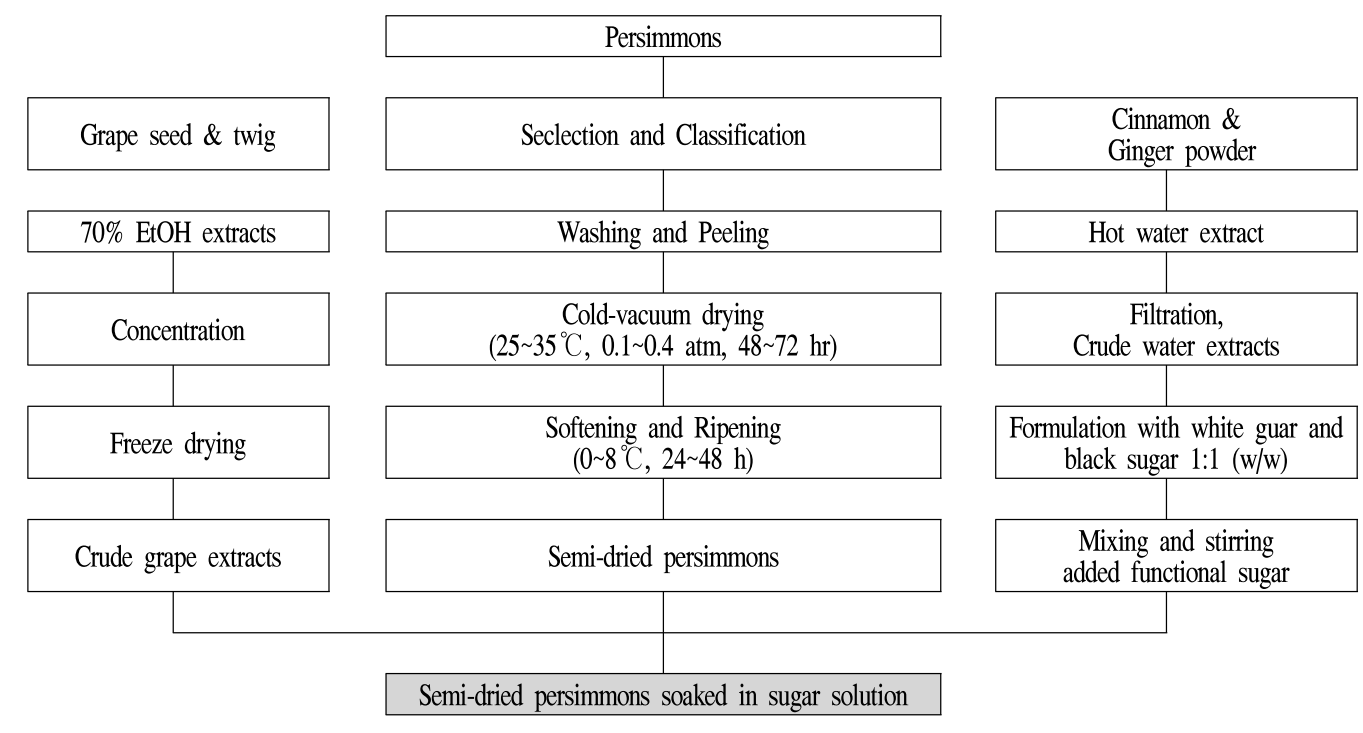

Fig. 1. Procedure for the preparation of semi-dried persimmons soaked in sugar solution. 
Table 1. Ingredient composition of the soaking solution with different sugar concentration

\begin{tabular}{|c|c|c|c|c|c|}
\hline \multirow{2}{*}{ Materials } & \multicolumn{5}{|c|}{ Soaking solution ${ }^{2)}$} \\
\hline & So & S5 & S10 & S15 & $\mathrm{S} 20$ \\
\hline Water & 100.0 & 90.0 & 85.0 & 80.0 & 75.0 \\
\hline Sugar ${ }^{1)}$ & - & 5.0 & 10.0 & 15.0 & 20.0 \\
\hline Xylitol & - & 2.0 & 2.0 & 2.0 & 2.0 \\
\hline Cinnamon & - & 0.6 & 0.6 & 0.6 & 0.6 \\
\hline Ginger powder & - & 0.2 & 0.2 & 0.2 & 0.2 \\
\hline Crystalline fructose & - & 0.2 & 0.2 & 0.2 & 0.2 \\
\hline Polydextrose & - & 1.0 & 1.0 & 1.0 & 1.0 \\
\hline Xanthan gum & - & 0.2 & 0.2 & 0.2 & 0.2 \\
\hline Guar gum & - & 0.3 & 0.3 & 0.3 & 0.3 \\
\hline Chicory fiber & - & 0.2 & 0.2 & 0.2 & 0.2 \\
\hline Stevia & - & 0.1 & 0.1 & 0.1 & 0.1 \\
\hline Citric acid & - & 0.1 & 0.1 & 0.1 & 0.1 \\
\hline Ascorbic acid & - & 0.1 & 0.1 & 0.1 & 0.1 \\
\hline Total $(\%)$ & 100 & 100 & 100 & 100 & 100 \\
\hline
\end{tabular}

색 도

색도는 표준 백색판으로 보정된 colorimeter(CR-200, Minolta Co., Osaka, Japan)를 이용하여 측정하였으며, 색차 를 Hunter scale에 의한 L 값(lightness), a 값(rednessgreenness), b 값(yellowness-blueness) 및 chroma value를 측 정하였으며, 색차 $(\mathrm{E})$ 는 초기 색도를 대조구로 하여 다음 식의 계산식에 의하여 산출하였다.

$$
\begin{gathered}
=\left(L-L_{t}\right)^{2}+\left(a_{i}-a_{t}\right)^{2}+\left(b_{i}-b_{t}\right)^{2} \\
i=\text { initial, } t=\text { test }
\end{gathered}
$$

Chroma value $=a^{2}+b^{2}$

\section{갈변도}

갈변도는 색차계(CR-200, Minolta Co.)를 사용하여 L값 을 측정한 후 다음과 같은 식으로 계산하여 나타내었다.

$$
\begin{gathered}
\text { 변도 }(\%)=\frac{\left(L_{i}-L_{t}\right)}{L_{i}} \times 100 \\
i=\text { initial, } t=\text { test }
\end{gathered}
$$

\section{총당 함량}

총당은 phenol-sulfuric acid 법(10)으로 측정하였다. 시료 $1 \mathrm{~g}$ 을 $100 \mathrm{~mL}$ volumetric flask에 넣고 증류수로 정용하였으 며, 용액 $1 \mathrm{~mL}$ 를 test tube에 넣고 DNS reagent $1 \mathrm{~mL}$ 를 혼합한 후 $95^{\circ} \mathrm{C}$ 에서 15 분 동안 중탕시켰다. 상온에서 충분 히 냉각한 후 증류수 $3 \mathrm{~mL}$ 를 넣어 희석한 후 $546 \mathrm{~nm}$ 에서
흡광도를 측정하였으며 glucose를 표준물질로 사용하여 검 량선에 의하여 함량을 산출하였다.

\section{환원당 함량}

환원당은 DNS법(11)에 따라 추출 여액 $1 \mathrm{~mL}$ 에 DNS reagent $3 \mathrm{~mL}$ 을 첨가하고 5 분간 끓인 다음, 냉각한 후 550 $\mathrm{nm}$ 에서 흡광도를 측정하였으며, glucose의 검량선에 의하 여 함량을 산출하였다.

\section{유리당 함량}

유리당 함량은 Wilson 등(12)의 방법에 따라 분석용 시료 조제는 각 시료 $5 \mathrm{~g}$ 에 증류수 $25 \mathrm{~mL}$ 를 가하여 파쇄 추출한 후 acetonitrile로 $50 \mathrm{~mL}$ 정용한 다음 $0.45 \mu \mathrm{m}$ membrane filter로 여과한 것을 시험용액으로 하였고, 표준 시약은 fructose, glucose, maltose, sucrose, lactose(Sigma chemical Co., USA)를 일정량씩 혼합하여 증류수 $50 \mathrm{~mL}$ 로 녹인 후 acetonitrile로 $100 \mathrm{~mL}$ 까지 정용하여 사용하였다. 시료의 분 석은 HPLC(Waters 600E, Millipore Corporation, Milford, $\mathrm{MA}, \mathrm{USA})$ 를 이용하였고, 분석 조건은 carbohydrate analysis column $(300 \mathrm{~mm} \times 4 \mathrm{~mm})$ 을 사용하였으며, mobile phase는 acetonitrile : 증류수 혼합액(80:20, v/v), flow rate는 $1.0 \mathrm{~mL} / \mathrm{min}$, detector는 refractive index(Waters 410 Refractive Index)를 사용하였다.

\section{폴리페놀 산화효소 및 과산화효소 활성}

폴리페놀 산화효소(polyphenol oxidase, $\mathrm{PPO}$ ) 및 과산화 효소(peroxidase, POD) 활성은 Kim 등(13)의 방법으로 측정 하였다. $0.5 \%$ 의 polyvinylpolypyrrolidone(PVPP)를 함유하 는 $0.2 \mathrm{M}$ sodium phosphate buffer(pH 7.0) $20 \mathrm{~mL}$ 를 시료 $10 \mathrm{~g}$ 과 함께 homogenizer(Nissei AM-12, Nohon seiki Co., Tokyo, Japan)로 균질화 하여 $4^{\circ} \mathrm{C}, 3,000 \mathrm{rpm}$ 의 조건으로 10 분간 원심분리하여 그 상등액을 조효소액으로 하였다. $\mathrm{PPO}$ 는 조효소액 $0.8 \mathrm{~mL}$ 에 균질화 시 사용한 것과 동일한 buffer로 만든 $0.02 \mathrm{M}$ 의 catechol용액 $2.4 \mathrm{~mL}$ 를 넣어 420 $\mathrm{nm}$ 의 흡광도로 측정하였으며, 흡광도가 1 분당 0.001 변하 는 것을 1 unit(U)으로 나타내었다. POD는 $25 \mathrm{mM}$ guaiacol 과 $25 \mathrm{mM}$ 의 hydrogen peroxide를 함유한 $0.05 \mathrm{M}$ sodium phosphate buffer(pH 7.0) $2.8 \mathrm{~mL}$ 에 조효소액 $0.2 \mathrm{~mL}$ 을 넣어 $470 \mathrm{~nm}$ 의 흡광도로 측정하였으며, 흡광도가 1 분당 0.01 변하는 것을 1 unit(U)으로 나타내었다.

\section{폴리페놀 함량}

폴리페놀 함량은 Dewanto 등(14)의 방법에 따라 추출물 $100 \mu \mathrm{L}$ 에 $2 \%$ sodium carbonate $2 \mathrm{~mL}$ 과 $50 \%$ Folin-Ciocalteu reagent $100 \mu \mathrm{L}$ 을 가한 후 $720 \mathrm{~nm}$ 에서 흡광도를 측정하였으 며 gallic acid(Sigma-Aldrich Co., USA)의 검량선에 의하여 함량을 산출하였다. 


\section{플라보노이드 함량}

플라보노이드 함량은 Saleh와 Hameed(15)의 방법에 따 라 추출물 $100 \mathrm{~mL}$ 에 $5 \%$ sodium nitrite $0.15 \mathrm{~mL}$ 을 가한 후 $25^{\circ} \mathrm{C}$ 에서 6 분간 방치한 다음 $10 \%$ aluminium chloride $0.3 \mathrm{~mL}$ 를 가하여 $25^{\circ} \mathrm{C}$ 에서 5 분간 방치하였다. 다음 $1 \mathrm{~N}$ $\mathrm{NaOH} 1 \mathrm{~mL}$ 를 가하고 vortex 상에서 가한 후 $510 \mathrm{~nm}$ 에서 흡광도를 측정하였으며 rutin hydrate(Sigma-Aldrich Co., USA)의 검량선에 의하여 함량을 산출하였다.

\section{프로안토시아니딘 함량}

프로안토시아니딘 함량은 Vanillin-sulfuric acid 법(16)에 따라 시료 $200 \mu \mathrm{L}$ 에 $1.2 \%$ vanillin 용액 $500 \mu \mathrm{L}$ 와 $20 \%$ sulfuric acid $500 \mu \mathrm{L}$ 를 혼합하여 20 분간 방치한 후 $500 \mathrm{~nm}$ 에 서 흡광도를 측정하였으며 (+)-catechin(Sigma-Aldrich Co., USA)의 검량선에 의하여 함량을 산출하였다.

\section{총 비타민 C 함량}

비타민 C(ascorbic acid)는 식품공전 방법에 의해 2,4-dinitrophenylhydrazine 법을 이용하여 측정하였으며, 일 정 시료에 $5 \%(\mathrm{w} / \mathrm{v})$ metaphosphoric acid를 가하여 homogenizer (Nissei AM-12, Nihon seiki Co., Tokyo, Japan)로 10,000 $\mathrm{rpm}$ 에서 1 분간 마쇄 후, 원심분리 $\left(4^{\circ} \mathrm{C}, 5,000 \mathrm{rpm}, 10 \mathrm{~min}\right)$ 한 다음 상등액을 Whatman No. 1 여과지로 여과하여 비타민 $\mathrm{C}$ 추출물을 사용하였다. 비타민 $\mathrm{C}$ 함량 측정을 위하여 시료 $2 \mathrm{~mL}$ 에 0.2\% 2,4-dihloropenolindophenol 용액을 가하고 1분 간 방치 후, thiourea-metaphosphoric acid 용액 $2 \mathrm{~mL}$ 와 2,4-dinitrophenylhydrazine(DNP) 용액 $1 \mathrm{~mL}$ 를 가한 다음 $50^{\circ} \mathrm{C}$ 에서 1 시간 반응시킨 후 얼음물로 냉각시켰다. 다음 $85 \%$ sulfuric acid $5 \mathrm{~mL}$ 를 천천히 첨가한 후 실온에서 30 분 간 방치하고 $540 \mathrm{~nm}$ 에서 흡광도를 측정하였으며, $\mathrm{L}(+)-$ ascorbic acid(Junsei Chemical Co., Japan)의 검량선에 의하 여 ascorbic acid의 함량을 산출하였다.

\section{$\mathrm{DPPH}$ 라디칼 소거활성}

Blois 의 방법(17)에 따라 시액 $0.2 \mathrm{~mL}$ 에 $0.4 \mathrm{mM}$ 1,1diphenyl-2-picryl-hydrazyl(DPPH) 용액 $0.8 \mathrm{~mL}$ 를 가하여 10 분간 방치 한 다음 $525 \mathrm{~nm}$ 에서 흡광도를 측정하였으며 계산식, DPPH radical scavenging ability $(\%)=100-[(\mathrm{OD}$ of sample/OD of control) $\times 100]$ 에 의하여 활성도를 산출하였 다.

\section{상관관계 분석 및 통계처리}

모든 실험은 3회 반복으로 하여 평균치와 표준편차로 나타내었고, 유의성 검증은 SPSS(12, SPSS Inc., Chicago, IL, USA) software를 이용하여 Duncan's multiple range test 를 행하였다. 또한 폴리페놀 산화효소, 과산화효소, 색차 및 갈변도 간의 상관관계는 Pearson's correlation analysis를 통하여 분석하였다.

\section{결과 및 고찰}

\section{색도 및 갈변도}

반건시 당액침지 가공품을 20 일간 $7^{\circ} \mathrm{C}$ 에 저장 후 색도 및 갈변도를 비교한 결과는 Table 2 와 같다. 농도에 따라 당액침지한 반건시의 명도 및 채도의 경우 당액침지 처리 없이 저장한 대조구(control)와 비교하면 월등히 높게 나타 났으며, 색차 및 갈변도는 낮게 나타났다. SO(sugar 0\%)의 경우 대조구에 비해 명도와 채도는 높게 나타났으며 갈변되 는 정도가 다소 낮은 것으로 관찰되었지만, 삼투작용으로 저장 10 일 이후부터 외관이 허물어짐에 따라 품질열화가 발생하는 것을 알 수 있었다. 반면 S5 S20(sugar 5 20\%)의 경우 색의 선도 유지 및 갈변도가 저해되었는데, 당액 농도 가 증대될수록 색차 및 갈변도가 높아지는 것으로 관찰되었 다. 이는 더덕에 설탕의 첨가량이 증대됨에 따라 명도가

Table 2. Changes in color parameters, delta $\mathrm{E}$, and browning degree of semi-dried persimmons soaked in sugar solutions with the addition of different proportions of sugar concentration depending on storage at $7^{\circ} \mathrm{C}$ for 20 days

\begin{tabular}{|c|c|c|c|c|c|c|}
\hline \multirow{2}{*}{ Samples ${ }^{1)}$} & \multicolumn{2}{|c|}{$\mathrm{L}^{*}$ values } & \multicolumn{2}{|c|}{ Chroma values } & \multirow{2}{*}{ Delta E } & \multirow{2}{*}{$\begin{array}{l}\text { Browning } \\
\text { degree }(\%)\end{array}$} \\
\hline & 0 days & 20 days & 0 days & 20 days & & \\
\hline Control & $44.67 \pm 0.85$ & $22.30 \pm 0.85$ & $9.18 \pm 0.73$ & $3.09 \pm 0.12$ & $23.35 \pm 1.71$ & $50.04 \pm 2.71$ \\
\hline So & $48.20 \pm 0.95^{22, \mathrm{a} 3)}$ & $27.51 \pm 0.65^{\mathrm{e}}$ & $0.69 \pm 0.08^{b}$ & $13.00 \pm 0.04^{\mathrm{a}}$ & $26.37 \pm 0.54^{\mathrm{a}}$ & $42.93 \pm 0.53^{\mathrm{a}}$ \\
\hline S5 & $44.15 \pm 0.67^{\mathrm{b}}$ & $42.65 \pm 0.01^{\mathrm{a}}$ & $0.69 \pm 0.08^{b}$ & $8.71 \pm 0.07^{\mathrm{e}}$ & $6.06 \pm 0.02^{\mathrm{e}}$ & $3.38 \pm 1.47^{\circ}$ \\
\hline S10 & $43.94 \pm 0.36^{b}$ & $39.55 \pm 0.05^{b}$ & $0.70 \pm 0.03^{\mathrm{b}}$ & $12.05 \pm 0.04^{\mathrm{b}}$ & $7.77 \pm 0.04^{\mathrm{d}}$ & $9.99 \pm 0.79^{\mathrm{d}}$ \\
\hline S15 & $41.89 \pm 0.55^{\mathrm{c}}$ & $35.30 \pm 0.07^{\mathrm{c}}$ & $0.74 \pm 0.01^{\mathrm{ab}}$ & $10.70 \pm 0.10^{\mathrm{c}}$ & $11.99 \pm 0.08^{\mathrm{c}}$ & $15.71 \pm 1.27^{\mathrm{c}}$ \\
\hline S20 & $40.38 \pm 0.23^{\mathrm{d}}$ & $32.76 \pm 0.03^{\mathrm{d}}$ & $0.82 \pm 0.06^{\mathrm{a}}$ & $10.05 \pm 0.04^{\mathrm{d}}$ & $14.66 \pm 0.03^{\mathrm{b}}$ & $18.88 \pm 0.46^{b}$ \\
\hline
\end{tabular}

\footnotetext{
${ }^{1)}$ S0, sugar $0 \%$; S5, sugar 5\%; S10, sugar 10\%; S15, sugar 15\%; S20, sugar $20 \%$.

${ }^{2)}$ Values are mean \pm standard deviation of triplicate determinations.

${ }^{3}$ Different superscripts within a column $(\mathrm{a}-\mathrm{e})$ indicate significant differences $(\mathrm{p}<0.05)$.
} 
감소한다는 Jin 등(18)의 보고와 유사함을 알 수 있었으며, 당액 농도가 증대됨에 따라 과실의 갈변도가 높아지는 현상 은 당액에 함유하는 흑설탕의 색도가 과실에 영향을 미침에 따른 결과로 생각된다. 한편 과실의 명도 및 채도의 경우 $\mathrm{S} 10$ 에서 높은 값을 나타내다가 그 이상의 농도에서 감소하 는 것으로 보아 당액 적정 농도에서는 마일라드반응을 비롯 한 효소적 갈변을 억제할 수 있는 것으로 관찰되었으며, $\mathrm{S} 10$ 의 경우 갈변도와 색상을 유지할 수 있는 적정 농도의 조건으로 생각된다.

\section{총당, 환원당 및 유리당 함량}

식품 중에 존재하는 당류는 화학적으로 환원성을 갖는

Table 3. Changes in total sugar content, reduced sugar content and sugar free contents of semi-dried persimmons soaked in sugar solutions with the addition of different proportions of sugar concentration depending on storage at $7^{\circ} \mathrm{C}$ for 20 days

\begin{tabular}{|c|c|c|c|c|c|}
\hline \multirow{2}{*}{ Samples ${ }^{1)}$} & \multirow{2}{*}{$\mathrm{TSC}^{2)}$} & \multirow{2}{*}{$\mathrm{RSC}^{3)}$} & \multicolumn{2}{|c|}{ Free sugar contents } & \multirow{2}{*}{ Tota } \\
\hline & & & Glucose & Fructose & \\
\hline Control & $80.05 \pm 2.42$ & $74.87 \pm 2.61$ & 32.49 & 35.12 & 67.61 \\
\hline So & $54.25 \pm 1.96^{4)(d)}$ & $47.37 \pm 0.63^{\mathrm{d}}$ & 18.33 & 21.85 & 40.18 \\
\hline S5 & $80.18 \pm 2.30^{c}$ & $66.52 \pm 2.40^{b}$ & 28.97 & 32.67 & 61.64 \\
\hline S10 & $83.35 \pm 0.45^{b}$ & $71.49 \pm 1.52^{\mathrm{c}}$ & 30.85 & 34.84 & 65.69 \\
\hline S15 & $84.15 \pm 1.22^{b}$ & $74.77 \pm 1.81^{\mathrm{a}}$ & 38.23 & 41.95 & 80.18 \\
\hline $\mathrm{S} 20$ & $88.64 \pm 1.73^{\mathrm{a}}$ & $76.12 \pm 1.64^{a}$ & 42.03 & 42.25 & 84.28 \\
\hline
\end{tabular}

${ }^{1)}$ S0, sugar 0\%; S5, sugar 5\%; S10, sugar 10\%; S15, sugar 15\%; S20, sugar $20 \%$. ${ }^{2)}$ TSC, total sugar content.

${ }^{33} \mathrm{RSC}$, reducing sugar content.

${ }^{4)}$ Values are mean \pm standard deviation of triplicate determinations.

${ }^{5}$ Different superscripts within a column (a-d) indicate significant differences ( $\left.p<0.05\right)$.
환원당과 환원성을 갖지 않는 비환원당으로 나눌 수 있으며 이를 합하여 총당이라고 하고 과실에서 당분은 향기 생성과 단맛에도 영향을 주는 주요 성분이라 할 수 있다(19). 기호 성에 영향을 주는 단맛과 연관이 있는 총당, 환원당 및 유리 당 함량을 반건시 당액침지 가공품의 20 일간 $7^{\circ} \mathrm{C}$ 에 저장 후 비교한 결과는 Table 3 과 같다. 당액침지 처리 없이 저장 한 대조구(control)의 총당, 환원당 및 유리당 함량은 각각 $80.05 \%, 74.87 \%$ 및 $67.61 \%$ 이었으나, SO(sugar $0 \%$ )의 경우 각각 $54.25 \%, 47.37 \%$ 및 $40.18 \%$ 로 상당량의 당이 삼투작용 때문에 용출된 것으로 나타났다. 반면 S5 S20(sugar 5 20\%)의 경우 당의 농도가 증대될수록 총당, 환원당, 유리 당 함량 또한 증가하는 것으로 나타났다. Youn 등(20)과 $\mathrm{Kim}$ 등(21)은 사과에서 삼투 처리한 시료는 처리하지 않은 시료보다 glucose와 fructose 함량은 더 낮았으며 삼투용액 의 농도가 높아질수록 총당 및 유리당 함량이 증가하였고, 설탕용액에서 유입되는 것으로 추정한다고 보고하였으며 이는 본 연구의 결과와 일치하였다. 당액침지 가공품의 경 우 과실의 형태를 유지하기 위해서는 과실과 침지액간의 농도 조절이 무엇보다 중요하며 상호 간의 조건이 적합하지 않을 시 수분의 용출과 함께 유기산과 유리당 또한 용출된 다. S5의 경우 환원당과 유리당의 함량은 대조구에 비해 감소했지만, S10은 유사한 함량을 나타내었으며 S15 및 $\mathrm{S} 20$ 의 경우 과실에 함유하는 당의 농도가 증가하는 것으로 나타났다. 이는 $\mathrm{S} 10$ 은 과실과 당액간의 삼투작용을 조절할 수 있는 적정 농도 조건으로 생각되며, 반건시의 당액으로 적합할 것으로 생각된다.
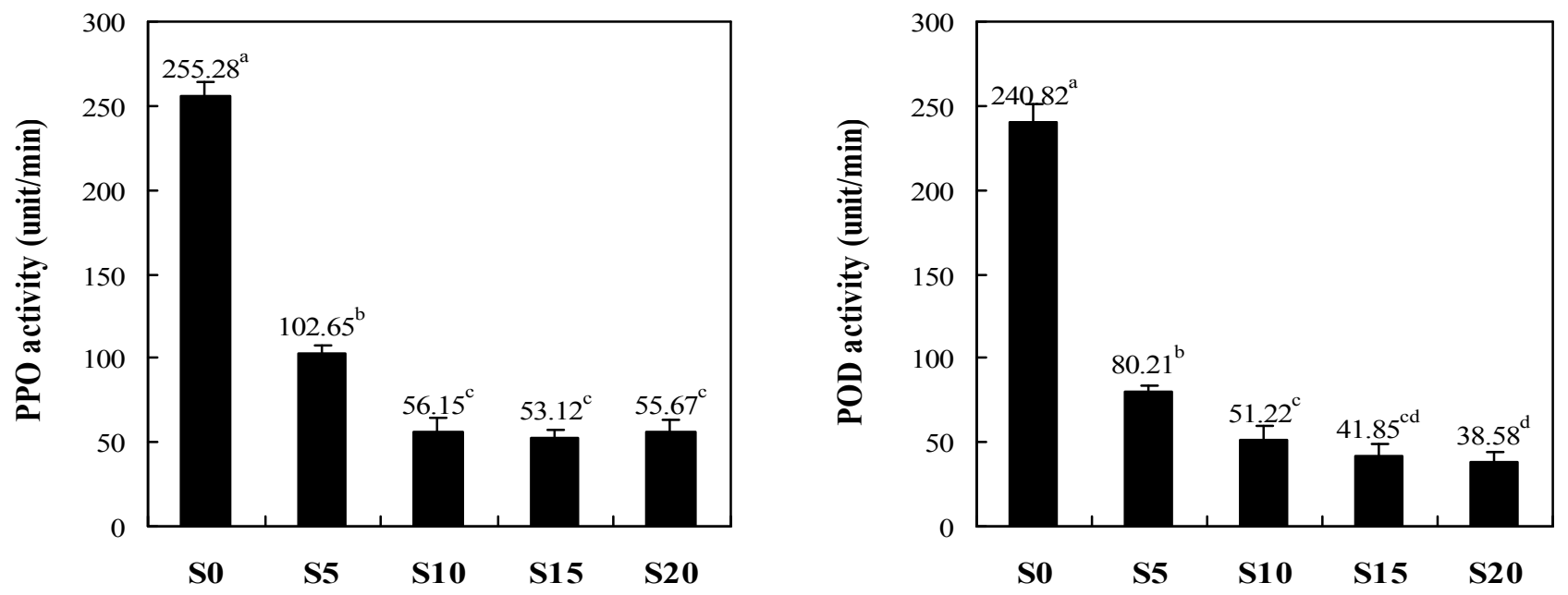

Fig. 2. Polyphenol oxidase (PPO), peroxidase (POD) activity of semi-dried persimmons soaked in sugar solutions with the addition of different proportions of sugar concentration depending on storage at $7^{\circ} \mathrm{C}$ for 20 days.

S0, sugar 0\%; S5, sugar 5\%; S10, sugar 10\%; S15, sugar 15\%; S20, sugar 20\%. Values are mean \pm standard deviation of triplicate determinations. Bars/mean values with different letters are significant differences $(\mathrm{p}<0.05)$. 


\section{폴리페놀 산화효소 및 과산화효소 활성}

폴리페놀 산화효소(polyphenol oxidase, PPO) 및 과산화 효소(peroxidase, POD)는 저장 중 과일 채소류의 품질변화 를 나타내는 대표적인 갈변 관련 효소로 색도와 함께 갈변 측정의 중요한 지표로 이용된다(13). 반건시 당액침지 가공 품을 20 일간 $7{ }^{\circ} \mathrm{C}$ 에 저장 후 폴리페놀 산화효소 및 과산화효 소 활성을 비교한 결과는 Fig. 2와 같다. SO(sugar 0\%)의 경우 폴리페놀 산화효소 및 과산화효소 활성이 각각 255.28 unit/min 및 $240.82 \mathrm{unit} / \mathrm{min}$ 로 높은 활성을 나타내었다. 반 면 S5 S20(sugar 5 20\%)의 폴리페놀 산화효소 활성은 각각 102.65 unit/min, 56.15 unit/min, 53.12 unit/min 및 55.67 unit/min로 월등히 저해되는 것으로 관찰되었으며, S10 이 후부터는 유사한 활성을 나타내었다. 한편 과산화효소 활 성은 S5 S20에서 각각 80.21 unit/min, 51.22 unit/min, 41.85 unit/min 및 $38.58 \mathrm{unit} / \mathrm{min}$ 로 당액 농도가 증대됨에 따라 유의적인 활성의 저하를 나타내었다. 과일 채소류에서 발 생하는 갈변현상은 크게 폴리페놀 산화효소와 과산화효소 가 관여하는 효소적 갈변과 성분 상호 간의 화학적 변화 때문에 발생하는 비효소적 갈변으로 구분되며, 신선 편이 식품 가공 시 발생하는 갈변은 주로 갈변효소에 의해 발생 하는 경우가 대부분이다(22). 갈변효소 중 자연계에 널리 존재하는 폴리페놀 산화효소는 $\mathrm{Cu}^{2+}$ 를 함유한 효소로 산소 존재하에서 페놀화합물(phenolic compounds)을 산화시켜 o-quinon compounds를 만들고 이들 물질이 서로 중합되면 서 갈색 또는 적색의 갈변물질을 생성하게 된다(23). 따라서 Cho 등(24)은 폴리페놀 산화효소 활성이 낮은 것은 효소적 갈변 현상이 억제되었음을 의미한다고 보고하였으며, 이는 당액 처리로 갈변 관련 효소의 활성이 억제되었음을 의미한 다. Table 2에서 확인한 바와 같이 명도가 감소하고 채도값 이 증가하는 경향은 색의 변화가 갈변정도를 나타내며 당의 농도가 증대됨에 따라 갈변 관련 효소의 활성은 저해되는
것으로 나타났으나 갈변도의 증가는 흑설탕의 색도가 과실 에 침착함에 따른 현상으로 생각된다.

\section{페놀화합물 함량, 비타민 C 함량 및 $\mathrm{DPPH}$ 라디칼 소거 활성}

반건시 당액침지 가공품을 20 일간 $7^{\circ} \mathrm{C}$ 에 저장 후 폴리페 놀, 플라보노이드 및 프로안토시아니딘 함량, 비타민 C 함 량 및 DPPH 라디칼 소거활성을 비교한 결과는 Table 4와 같다. 당액침지 처리 없이 저장한 대조구(control)의 폴리페 놀, 플라보노이드, 프로안토시아니딘 및 비타민 C 함량의 경우 $\mathrm{g}$ 당 각각 $1.30 \mathrm{mg}, 0.21 \mathrm{mg}, 1.05 \mathrm{mg}$ 및 $6.38 \mathrm{mg}$ 의 함량이 검출되었으며, $\mathrm{DPPH}$ 라디칼 소거활성은 $30.35 \%$ 의 활성을 나타내었다. $\mathrm{SO}$ (sugar $0 \%$ )는 $\mathrm{g}$ 당 각각 $0.76 \mathrm{mg}, 0.27$ $\mathrm{mg}, 0.45 \mathrm{mg}$ 및 $2.54 \mathrm{mg}$ 로 상당량의 기능물질이 당과 함께 용출된 것으로 나타났으며, DPPH 라디칼 소거활성 또한 대조구에 비해 감소하였다. 식물에 존재하는 많은 phytochemical중 phenol성 화합물은 이차 대사산물로, 이들 의 함량이 높을수록 항산화 활성은 증가하며, 항콜레스테 롤 작용, 정장작용, 항암 및 항산화 작용 등의 생리적 효과도 높아지는 것으로 알려져 있다(25). 현재까지 약 4,000여 종 이 알려진 플라보노이드류는 항산화 작용, 순환기계 질환 의 예방, 항염증, 항알레르기, 항균, 항바이러스, 지질저하 작용, 면역증강 작용, 모세혈관 강화작용 등의 효능을 나타 내는 것으로 알려졌으며 건조 및 전처리 방법에 따라 그 함량에 차이가 있다고 보고된 바 있다(26). 한편 당액 침지 가공품의 경우 S0와 비교하면 S5 S20(sugar 5 20\%)에서 높은 기능물질을 함유하는 것으로 나타났으며, 특이한 현 상은 $\mathrm{S} 5$ 와 비교하면 $\mathrm{S} 10$ 에서 그 함량과 활성이 증대되는 반면 S15와 S20에서는 다시 감소하는 결과를 나타내었다. Lazarides 등(6)은 과일과 채소 등 높은 삼투압의 당과 염 용액에 침지할 경우 식품과 용액 사이에 삼투압 효과로

Table 4. Total polyphenol, flavonoid, proanthocyanidin, ascorbic acid contents and DPPH radical scavenging ability of semi-dried persimmons soaked in sugar solutions with the addition of different proportions of sugar concentration depending on storage at $7{ }^{\circ} \mathrm{C}$ for 20 days

\begin{tabular}{cccccc}
\hline Samples $)^{1)}$ & $\begin{array}{c}\text { Polyphenols } \\
\left(\mathrm{mg} \mathrm{GAE}^{2} / \mathrm{g}\right)\end{array}$ & $\begin{array}{c}\text { Flavonoids } \\
\left(\mathrm{mg} \% \mathrm{RHE}^{3} / \mathrm{g}\right)\end{array}$ & $\begin{array}{c}\text { Proanthocyanidins } \\
(\mathrm{mg} \mathrm{CE} / \mathrm{g})\end{array}$ & $\begin{array}{c}\text { Total ascorbic } \\
\text { acid }(\mathrm{mg} / \mathrm{g})\end{array}$ & $\begin{array}{c}\text { DPPH radical } \\
\text { scavenging ability }(\%)\end{array}$ \\
\hline Control & $1.30 \pm 0.02^{5)}$ & $0.21 \pm 0.00$ & $1.05 \pm 0.01$ & $6.38 \pm 0.16$ & $30.35 \pm 0.10$ \\
\hline S0 & $0.76 \pm 0.02^{\mathrm{d})}$ & $0.27 \pm 0.00^{\mathrm{a}}$ & $0.45 \pm 0.03^{\mathrm{c}}$ & $2.54 \pm 0.00^{\mathrm{e}}$ & $28.19 \pm 0.05^{\mathrm{d}}$ \\
S5 & $1.47 \pm 0.00^{\mathrm{b}}$ & $0.20 \pm 0.00^{\mathrm{bc}}$ & $1.24 \pm 0.00^{\mathrm{b}}$ & $7.76 \pm 0.04^{\mathrm{b}}$ & $35.23 \pm 0.69^{\mathrm{b}}$ \\
S10 & $1.66 \pm 0.01^{\mathrm{a}}$ & $0.21 \pm 0.01^{\mathrm{b}}$ & $1.26 \pm 0.00^{\mathrm{a}}$ & $12.29 \pm 0.00^{\mathrm{a}}$ & $65.34 \pm 0.44^{\mathrm{a}}$ \\
S15 & $1.41 \pm 0.04^{\mathrm{c}}$ & $0.19 \pm 0.00^{\mathrm{cd}}$ & $1.23 \pm 0.00^{\mathrm{b}}$ & $6.05 \pm 0.02^{\mathrm{c}}$ & $33.37 \pm 0.04^{\mathrm{c}}$ \\
S20 & $1.40 \pm 0.00^{\mathrm{c}}$ & $0.18 \pm 0.01^{\mathrm{d}}$ & $1.22 \pm 0.00^{\mathrm{b}}$ & $5.05 \pm 0.01^{\mathrm{d}}$ & $20.98 \pm 0.03^{\mathrm{e}}$ \\
\hline
\end{tabular}

\footnotetext{
${ }^{1)}$ S0, sugar 0\%; S5, sugar 5\%; S10, sugar 10\%; S15, sugar 15\%; S20, sugar $20 \%$.

${ }^{2)} \mathrm{GAE}$, gallic acid equivalents.

${ }^{3)} \mathrm{RHE}$, rutin hydrate equivalents.

${ }^{4)} \mathrm{CE}$, catechin hydrate equivalents.

${ }^{5)}$ Values are mean \pm standard deviation of triplicate determinations.

${ }^{6}$ Different superscripts within a column $(\mathrm{a}-\mathrm{e})$ indicate significant differences $(\mathrm{p}<0.05)$.
} 
인하여 용질의 확산, 용액 속으로 수분 이동, 식품으로부터 용질 용출 등이 일어난다고 하였으며, 본 연구의 결과에서 삼투작용이 일어남과 동시에 유용성분 또한 용출될 수 있음 을 나타내며 과실과 당의 농도 어느 한쪽이 낮거나 높을 시 침지되는 과실의 열매껍질이 삼투작용으로 인해 물러지 면서 기능성분의 용출이 발생한 것으로 생각된다.

\section{상관관계}

반건시 당액침지 가공품을 20 일간 $7^{\circ} \mathrm{C}$ 에 저장 후 반건시 의 폴리페놀 산화효소, 과산화효소, 색차 및 갈변도와의 상관관계를 분석한 결과는 Table 5 와 같다. 폴리페놀 산화 효소 활성과 과산화효소 활성, 색차 및 갈변도간의 상관관 계가 높았으며, 상관계수는 각각 $0.933,0.957,0.824$ 로 양의 상관관계를 보였다 $(\mathrm{p}<0.01)$. 과산화효소 활성이 높을수록 색차와 갈변도가 높았으며 $(\mathrm{p}<0.01)$. 그리고 색차와 갈변도 간에도 0.943 으로 양의 상관계수를 나타내었다( $\mathrm{p}<0.01)$. 따 라서 폴리페놀 산화효소 및 과산화효소와 색차, 갈변도 상 호간의 상호 상관관계가 있어 당액침지 반건시의 품질특성 은 나타내는 색의 변화나 갈변도를 측정함으로서 효소활성 또한 변화정도를 추측할 수 있을 것으로 판단된다.

Table 5. Correlation coefficients among polyphenol oxidase, peroxidase, delta $\mathrm{E}$ and browning degree of semi-dried persimmons soaked in sugar solutions with the addition of different proportions of sugar concentration depending on storage at $7^{\circ} \mathrm{C}$ for 20 days

\begin{tabular}{ccccc}
\hline Factor $^{1)}$ & PPO & POD & Delta $\mathrm{E}$ & BD \\
\hline PPO & 1.000 & $0.933^{* *}$ & $0.957^{* *}$ & $0.824^{* *}$ \\
POD & & 1.000 & $0.967^{* *}$ & $0.835^{* *}$ \\
Delta $\mathrm{E}$ & & & 1.000 & $0.943^{* *}$ \\
BD & & & & 1.000 \\
\hline
\end{tabular}

${ }^{1)} \mathrm{PPO}$, polyphenol oxidase; POD, peroxidase; $\mathrm{BD}$, browning degree. ${ }^{*} \mathrm{p}<0.05,{ }^{* \star \mathrm{p}}<0.01$.

\section{요 약}

반건시의 활용성 증대를 위하여 당액침지형 반건시를 제조하였으며 당 조성에 따른 반건시의 이화학적 특성 및 갈변 저해 효과를 검토하였다. 명도와 채도는 S5(sugar 5\%), $\mathrm{S} 10$ (sugar $10 \%$ )에서 높았고 그 이상의 농도에서는 감소하 는 경향을 나타내었다. 총당, 환원당 및 유리당 함량은 당의 농도가 증대될수록 증가하였으며, $\mathrm{S} 5$ 는 대조구에 비해 감 소하는 경향을 나타내었으나 $\mathrm{S} 10$ 은 유사한 함량을 보였으 며 S15 및 S20의 경우 과실에 함유하는 당의 농도가 증가하 는 것으로 나타났다. 당액침지형 반건시와 갈변효소간의 관계를 알아보기 위해 폴리페놀 산화효소와 과산화효소를 측정하였으며, 당액 농도가 증대됨에 따라 활성이 저해하
는 경향을 나타냈고 $\mathrm{S} 10$ 이후부터는 유사한 활성을 보였다. 폴리페놀, 플라보노이드, 프로안토시아니딘 및 비타민 C 함량은 다른 처리구와 비교하면 $\mathrm{S} 10$ 이 가장 높은 함량을 보여 식품과 당액 사이에 삼투압 때문에 당액으로 용출되는 함량이 감소하는 것으로 나타났다. DPPH 라디칼 소거활성 은 $\mathrm{S} 10$ 에서 $65.34 \%$ 로 가장 높은 활성을 나타내었다. 이상 의 결과 당액침지 시 삼투작용으로 적정 농도의 확립이 요구되며 갈변억제 및 영양적인 가치 등의 품질특성을 고려 하였을 때 $10 \%$ 설탕을 첨가한 당액 침지법이 반건시 가공 품을 제조하는 데 있어 효과적인 방안이 될 것으로 생각된 다.

\section{References}

1. Kang BH, Jo MY, Hur SS, Shin KS, Lee DS, Lee SH, Lee JM (2012) Isolation and identification of contaminated organisms on dried persimmon. Korean $\mathbf{J}$ Food Preserv, 19, 939-945

2. Kim YJ, Lee SJ, Kim MY, Kim GR, Chung HS, Park HJ, Kim MO, Kwon JH (2009) Physicochemical and organoleptic qualities of sliced-dried persimmons as affected by drying methods. Korean J Food Sci Technol, 41, 64-68

3. Seo JH, Jeong YJ, Kim KS (2000) Physiological characteristics of tannins isolated from astringent persimmon fruits. Korean J Food Sci Technol, 32, 212-217

4. Jung KM, Song IK, Cho DH, Chou YD (2004) Quality properties of semi-dried persimmons with various drying methods and ripeness degree. Korean J Food Preserv, 11, 189-194

5. Park HW, Kim SH, Lee SA, Park JD (2012) Quality change of chill-stored dried persimmons affected by cinnamon extract pre-treatment and packaging condition. Korean J Packaging Sci Technol, 18, 9-14

6. Lazarides HN, Katsanidis E, Nickolaidis A (1995) Mass transfer kinetics during osmotic preconcentration aiming at minimal solid uptake. J Food Eng, 25, 151-166

7. Sablani SS, Rahman MS, Al-Sadeiri DS (2002) Equilibrium distribution data for osmotic drying of apple cubes in sugar-water solution. J Food Eng, 52, 193-199

8. Song NE, Song YR, Kim JH, Kim YE, Han AR, Jeong DY, Baik SH (2011) Development of sugar-soaked black soybean snack and its quality change on functional components. J Korean Soc Food Sci Nutr, 40, 853-859

9. Paek JK, Kim JH, Yoon SJ (2006) Quality characteristics 
of Ginseng Jung Kwa after different soaking times in sugar syrup. Korean J Food Cookery Sci, 22, 792-798

10. Kim JY, Yi YH (2010) pH, acidity, color, amino acids, reducing sugars, total sugars, and alcohol in puffed millet powder containing millet Takju during fermentation. Korean J Food Sci Technol, 42, 727-732

11. Miller GL (1959) Use of dinitrosalicylic acid reagent for determination of reducing sugar. Anal Chem, 31, 426-428

12. Wilson AM, Work TM, Bushway AA, Bushway RJ (1981) HPLC determination of fructose, glucose and sucrose in potatoes. J Food Sci, 46, 300-306

13. Kim DH, Kim SM, Kim HB, Moon KD (2012) Effects of optimized co-treatment conditions with ultrasound and low-temperature blanching using the response surface methodology on the browning and quality of fresh-cut lettuce. Korean J Food Preserv, 19, 470-476

14. Dewanto V, Wu X, Adom KK, Liu RH (2002) Thermal processing enhances the nutritional value of tomatoes by increasing total antioxidant activity. J Agric Food Chem, 50, 3010-3014

15. Saleh ES, Hameed A (2008) Total phenolic contents and free radical scavenging activity of certain Egyptian Ficus species leaf samples. Food Chem, 114, 1271-1277

16. Baoshan S, Jorge MR, Isabel S (1998) Critical factors of vanillin assay for catechins and proanthocyanidins. J Agric Food Chem, 46, 4267-4274

17. Blois MS (1958) Antioxidant determination by the use of a stable free radical. Nature, 26, 1199-1200

18. Jin TY, Wang MH (2013) Quality characteristics of
Codonopsis lanceolata tea manufactured with sugar. J Korean Soc Food Sci Nutr, 42, 753-758

19. Kim JW, Youn KS (2013) Effect of ripeness degree on the physicochemical properties and antioxidative activity of banana. Korean J Food Preserv, 20, 475-481

20. Youn KS, Lee JH, Choi YH (1996) Changes of free sugar and organic acid in the osmotic dehydration process of apples. Korean J Food Sci Technol, 28, 1095-1103

21. Kim GC, Lee SY, Kim KM, Kim Y, Kim JS, Kim HR (2011) Quality characteristics of hot-air and freeze dried apples slices after osmotic dehydration. J Korean Soc Food Sci Nutr, 40, 848-852

22. Moon SM, Kim HJ, Ham KS (2003) Purification and characterization of polyphenol oxidase from lotus root (Nelumbo nucifera G.). Korean J Food Sci Technol, 35, 791-796

23. Martinez MV, Whitaker JR (1995) The biochemistry and control of enzymatic browning. Trend Food Sci Technol, 6, 195-200

24. Cho JS, Kim DH, Park JH, Moon KD (2013) Analysis of browning degree on fresh-cut lotus root (Nelumbo nucifera G.) using image analysis. Korean J Food Preserv, 20, 760-765

25. Zhou ZH, Zhang YJ, Xiao R, Xu M, Yang CR (2005) Puerins A and B, two new 8-C substituted flavan-3-ols from Pu-er tea. J Agric Food Chem, 53, 8614

26. Kim HS, Hong MJ, Kang IY, Jung JY, Kim HK, Shin YS, Jun HJ, Suh JK, Kang YH (2009) Radical scavenging activities and antioxidant constituents of Oriental melon extract. J Bio-Environ Control, 18, 442-447 